\title{
Nostalgia za przyszłością: życie jako opowieść w listach Juliusza Słowackiego do matki ${ }^{1}$
}

Agata Sikora

TEKSTY DRUGIE 2018, NR 6, S. 267-282

DOI: 10.18318/td.2018.6.19

$\mathbf{W}$ lipcu 1838 roku Juliusz Słowacki pisze do swojej matki, Salomei Bécu, primo voto Słowackiej:

Nie mam żadnego przyjaciela, któremu bym o wszystkim mówić mógł otwarcie, więc niech te listy zastąpią mi wszystko: od tylu lat pisane co miesiąca, muszą być najlepszą historią życia mojego; z nich musisz mię znaćlepiej, niżja sam siebie, bo nigdy żurnalu nie piszę i nie wiem, jak się i o ile od siedmiu lat przemieniłem w sposobie czucia i pod względem rozumu. Jeżeli widzisz coś zdrożnego we mnie, jaką fałszywą dyrekcją myślom nadaną, ostrzeż mię, bądź mi przewodniczką, światłością w drodze. [299-300; 10.07.1838] ${ }^{2}$

1 Punktem wyjścia tego artykułu są wybrane wątki mojej pracy magisterskiej Od konwencji do ekspresji. Narodziny tożsamości nowoczesnej w świetle praktyki epistolograficznej na przykładzie listów Juliusza Słowackiego do matki przygotowanej pod kierunkiem prof. G. Godlewskiego.

2 J. Słowacki Listy do matki, oprac. Z. Krzyżanowska, Dzieła wybrane, red. J. Krzyżanowski, t. 6, Ossolineum, Wrocław-WarszawaGdańsk-Kraków 1979. Wszystkie cytaty z listów do matki pochodzą z tego wydania, w nawiasie kwadratowym podaję nr strony i datę.
Agata Sikora - dr, badaczka niezależna, krytyczka literacka, kulturoznawczyni. Autorka książki Szczerość. O wyłanianiu się nowoczesnego porzadku komunikacyjnego, wyróżniona w konkursie Narodowego Centrum Kultury na najlepszą pracę doktorską z zakresu nauk o kulturze, stypendystka Narodowego Centrum Nauki. Pracuje nad książką o kulturowych sprzecznościach liberalizmu. Kontakt: agata.anna.sikora@ gmail.com 
Michał Kuziak widział w tej korespondencji świadomie pisaną powieść rozwojową, która wraz z innymi zapisami autobiograficznymi - dziennikami, raptularzami i pamiętnikami - składa się na "mitologię prywatną Słowackiego"3. Ja natomiast, czerpiąc z narratywistycznych inspiracji, chciałabym potraktować listy pisane do czasu konwersji (12 lipca 1842 roku) jako świadectwo dylematów związanych z nowoczesnym postrzeganiem tożsamości jako refleksyjnego projektu rozgrywającego się w czasie.

Punktem wyjścia są dla mnie historycznie zorientowane ujęcia Charlesa Taylora i Anthony'ego Giddensa. Według nich wraz z upadkiem społeczeństwa tradycyjnego, zaniknięciem wspólnych ram moralnych i poszerzeniem pola wyborów, człowiek nowoczesny stanął przed koniecznością samodzielnego nadawania sensu swojej tożsamości poprzez tworzenie opowieści o swoim życiu ${ }^{4}$. Jestem przy tym świadoma, że po latach popularności w ostatnich dekadach XX wieku narratywizm doczekał się zdecydowanej krytyki. W 2004 roku Galen Strawson w Against Narrativity zdecydowanie odrzucił założenie pojawiające się m.in. u Taylora - że narracyjne rozumienie własnego „ja” jest uniwersalne i stanowi warunek dobrego życia. Argumentował, że możliwe jest także epizodyczne postrzeganie siebie, w którym podmiot utożsamia się wyłącznie ze swoim teraźniejszym doświadczeniem wewnętrznym (zna fakty biograficzne ze swojego życia, ale nie identyfikuje się z sobą samym z przeszłości) ${ }^{6}$. Peter Lamarque natomiast dowodził, że narracja literacka, w której każdy element jest znaczący dla artystycznej całości, nie jest dobrą analogią dla postrzegania ludzkiej egzystencjir. W odpowiedzi filozofka Marya Schechtman przyznała, że narratywizm w swojej obecnej postaci jest

3 M. Kuziak Kreacje epistolograficzne Juliusza Słowackiego (zarys problematyki), w: Sztuka pisania. O liście polskim w XIX wieku, red. J. Sztachelska, E. Dąbrowicz, Wydawnictwo Uw B, Białystok 2000, s. 94-95. Por.: M. Cieśla Słowackiego mit o sobie, „Teksty” 1974, nr 3.

Ch. Taylor Etyka autentyczności, przeł. A. Pawelec, Znak, Fundacja im. Stefana Batorego, Warszawa 1996; tegoż Źródła podmiotowości. Narodziny tożsamości nowoczesnej, przeł. M. Gruszczyński, O. Latek, A. Lipszyc i in., PWN, Warszawa 2001; A. Giddens Nowoczesność i tożsamość. " $a$ "i i społeczeństwo w epoce późnej nowoczesności, przeł. A. Szulżycka, PWN, Warszawa 2006.

5 Dzięki "zwrotowi narratywistycznemu" w naukach społecznych, pojęcie "narracja” wyszło nie tylko poza granice macierzystego dla niej literaturoznawstwa, ale i poza mury akademii. U progu XXI wieku bardziej bądź mniej świadomie odwoływały się do niego najróżniejsze dyskursy eksperckie: od psychologii przez marketing i coaching po politologię.

G. Strawson Against Narrativity, , Ratio” 2004 No. $17 / 4$.

7 P. Lamarque On the Distance between Literary Narratives and Real-Life Narratives, w: Narrative and Understanding Persons, ed. by D. Hutto, Cambridge University Press, Cambridge 2007. 
jeszcze słabo operacjonalizowalny: albo bowiem pojęcie „tożsamość narracyjna" jest traktowana tak szeroko, że staje się banałem, albo wikła się w sprzeczności, które wytknęli mu krytycy. Schechtman postuluje dalszą pracę, za punkt wyjścia przyjmującą wspólne dla narratywizmu założenie, że „złożoność tożsamości ujawnia się w różnych perspektywach patrzenia na nasze życie, które staramy się jakoś godzić i nawigować pośród nich w toku życia.Złożoność ta najlepiej daje się zrozumieć w kategoriach narracyjnych"8.

Jako antropologicznie zorientowana historyczka kultury, sięgając po narratywizm, wychodzę z odmiennych założeń. Robię, to nie dlatego, że wierzę w jego uniwersalność, ale ponieważ - jak zaświadcza przytoczona na początku prośba Słowackiego - ujęcie to koresponduje ze sposobem, w jaki poeta widział swoje życie.W szkicu tym zarówno samą tożsamość narracyjną, jak i sposoby jej konceptualizacji traktuję jako historycznokulturowy twór właściwy wyobraźni nowoczesnej rozwijającej się w kulturze druku (z jej monokazualnością, preferowaniem linearności, ciągów przyczynowo-skutkowych i paradygmatycznym gatunkiem literackim - powieścią) ${ }^{9}$. Inspiruję się ujęciami Taylora i Giddensa, mając nadzieję, że pozwolą mi one uchwycić swoistość temporalnego zorientowania tożsamościowej narracji Słowackiego - a jednocześnie, że swoistość ta odsłoni partykularność stojących za tymi koncepcjami kulturowych wyobrażeń.

Najpierw jednak chciałabym przyjrzeć się praktykom i gatunkom, w ramach których Słowacki tworzy opowieść o własnym życiu. Nigdy nie rozgrywa się ona bowiem w próżni.

\section{Między listem a dziennikiem}

Sam sposób powstawania tych listów zbliża je do diarystyki. Słowacki pisze je regularnie, często tworząc zapis przez parę dni (stawia wtedy kolejne daty w środku arkusza). Korespondencja z matką jest zatem „serią datowanych

8 M. Schechtman The narrative self, w: The Oxford Handbook of the Self, ed. by Sh. Gallagher, Oxford University Press, Oxford 2011, s. 415. Jeśli nie podano inaczej, tłumaczenie z angielskiego moje - A.S., konsultacja przekładów O. Kaczmarek.

9 M. McLuhan Galaktyka Gutenberga. Tworzenie człowieka druku, przeł. A. Wojtasik, wstęp G. Godlewski, red. naukowa G. Godlewski, K. Kukiełko-Rogozińska, NCK, Warszawa 2017. Można sobie wyobrazić futurystyczny scenariusz, w którym większość mediów działa na zasadzie dzisiejszego Snapchata i kulturę, w której to właśnie opisana przez Strawsona "epizodyczność" jawi się jako podejście "naturalne", ,oczywiste”, ,uniwersalne”. 


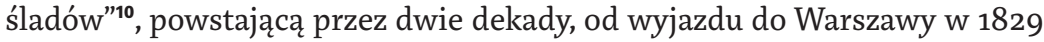
roku (pierwsze pisma nie zachowały się) do śmierci w 1849 roku. Od diariusza różni się tym, że piszący nie ma w nią wglądu - dlatego poeta prosił panią Bécu o przechowywanie listów, podkreślając, że „dziennika nigdy nie pisał" [334; 10.11.1841]. Nie była to jednak prawda - Słowacki nie dość że go prowadził , to jeszcze przesyłał jego fragmenty adresatce ${ }^{11}$.

Już jako dwudziestoparolatek uważał za konieczne przyjrzeć się swojemu życiu w perspektywie rozwojowej, spisując pamiętnik. Pierwszy znany nam rozdział12 powstał 17 lipca 1831 roku w Dreźnie i opisuje wyjazd do Wilna w 1817 roku oraz pierwsze próby poetyckie. Autor kończy notkę zapowiedzią:

W następującym rozdziale zmienię sposób pisania moich pamiętników będzie to dziennik niektórych dni mego życia, tak pisany,jakby był wtenczas, kiedy się one przytrafiały - bo nie chodzi mi o wystawienie wypadków tak, jak mi się one przez prizma dalekich wspomnień ukazują, ale chciałbym je pisać tak, jak wtenczas wzruszały moje uczucia. O jakżeby wszystkie zbladły, gdybym im dał koloryt zimny i blady uczuć moich teraźniejszych. [Nie] byłem zawsze taki, jaki jestem. [Przyczy]na z dziennika się okaże. ${ }^{13}$

Podstawowa różnica między pamiętnikiem a dziennikiem polega na tym, że ten pierwszy tworzy się z dystansu czasowego, drugi natomiast na bieżąco. Projektowana przez Słowackiego zmiana gatunkowa jest zatem zmianą usytuowania samego siebie wobec czasu i własnych przeżyć: „zmrożony” emocjonalnie podmiot teraźniejszy ma stać się medium oddającym przeszłe wypadki nie przez pryzmat wspomnień, lecz swoich ówczesnych, żywych jeszcze, wzruszeń. Tym samym daje wyraz wierze w moc własnej refleksyjności, zdolnej oddzielić właściwe uczucia przeżywane w przeszłości od ich obrazu ukształtowanego przez pamięć oraz uruchomić je, niezmienione, w pisaniu po latach.

Por. Ph. Lejeune Koronka. Dziennikjako seria datowanych śladów, przeł. i przyp. M i P. Rodakowie, "Pamiętnik Literacki" 2006,z. 4 .

Matka, od dawna przechowując listy syna i mogąc je ponownie odczytywać, mogła być tej nieścisłości, manipulacji bądź kłamstwa świadoma. Do naszych czasów zachowała się niewielka część zapisów autobiograficznych Słowackiego: kilka wpisów z pamiętnika/dziennika, diariusz podróży na Wschód (który ma charakter notatek), dziennik prowadzony w latach 1847-1849 utrzymany w duchu mistycznym, raptularz z lat 1843-1849.

3 J. Słowacki Pisma prozą, cz. 2, oprac. W. Floryan, Ossolineum, Wrocław 1952, s. 152. 
Potem jednak praktyka pisania o sobie ewoluuje ku diariuszowi poświęconemu teraźniejszości i nastawionemu na adresata. W liście z 7 marca 1832 roku poeta notuje: „Od jakiegoś czasu piszę dziennik umyślnie dlatego, abym Tobie, Mamo, szczegóły i wyjątki z niego mógł posyłać." [41; 7.03.1832].W lipcu 1832 roku twierdzi w liście, że "gwałt sobie zadając”, przepisuje „słowo w słowo" [41; 7.03.1832], choć tak naprawdę w subtelny, acz znaczący sposób manipuluje tekstem. Sama deklaracja, że daje się dostęp do osobistych zapisów, jest znacząca - ma dać adresatce poczucie „bezpośredniego” wglądu w przeżycia jej syna. Odsłanianie intymności staje się zatem gestem performatywnym, sposobem na podkreślenie szczególności więzi ${ }^{14}$.

Relacja między listem a dziennikiem jest zatem skomplikowana, na co zwracała uwagę już Stefania Skwarczyńska w Teorii listu:

Ten, kto przede wszystkim chce utrwalić siebie, swoje przeżycia, monologuje w kształcie dziennika; ta twórczość pozornie tak intymna może być pomyślana jako hołd przyjaźni, miłości, może być przeznaczona dla drugiej osoby. [...] Niekiedy podnieta do listu-dziennika wychodzi z założeń, epistolarnych raczej, nie monologicznych. Chęć udzielenia siebie w każdej chwili w całości duchowej osobie drugiej skłania do pisania fragmentów jak najczęściej. Te fragmenty, opatrzone datami, tworzą formalnie całość, a przeznaczone do wysłania drugiej osobie ogarnięte są w pewną większą całość ukształtowaną epistolarnie. ${ }^{15}$

Trzeba dodać, że autorka tej wciąż inspirującej, choć liczącej już niemal wiek monografii, była zwolenniczką traktowania adresata jako współautora listu ${ }^{16}$. Znamienne, że choć ten postulat teoretyczki nie znalazł odbicia w praktyce

14 O zmianie sposobu oddziaływania na adresata: od używania konwencji zgodnie ze społecznym rytuałem do odsłaniania „prawdy ja”, zob. A. Sikora Szczerość. O wyłanianiu się nowoczesnego początku komunikacyjnego, Wydawnictwa UW, Warszawa 2019 [w przygotowaniu]; analiza przepisywania dziennika Słowackiego: cz. II, rozdz. 3, podrozdz. "Delikatna scena” na dwa głosy. Inaczej akcenty rozkłada Elżbieta Rybicka, która twierdziła, że w XIX wieku postępowała autobiografizacja epistolografii, ponieważ piszący bardziej skupiali się na wyrażaniu siebie niż komunikacji z drugą osobą. Rybicka Antropologiczne i komunikacyjne aspekty dyskursu epistolograficznego, "Teksty Drugie” 2004, $\mathrm{nr} 4$.

15 S. Skwarczyńska Teoria listu, Towarzystwo Naukowe, Lwów 1937, s. 345. Uczona wskazuje, że możliwa jest również odwrotna sytuacja: prowadzenie dziennika w poczuciu intymności i dopiero wtórne udostępnianie go innym. W praktyce, jej zdaniem, przeważają formy pośrednie. 
edytorskiej i badawczej, to w przypadku tej korespondencji wytrwale tropiono wpływ, jaki na kształt listów Słowackiego miała Salomea Bécu'7. Sentymentalizm tych zapisów wprawia bowiem literaturoznawców w zakłopotanie.

\section{Dziwne losy „pomysłów sentymentalnych”}

Najbardziej otwarcie pisał o tym Zbigniew Sudolski: „Słowacki też, jak żaden z naszych epistolografów dziewiętnastowiecznych, zdawał sobie sprawę z sentymentalnego powinowactwa swojej korespondencji"18. Jak wielu innych badaczy przypisywał to jednak chęci dostosowania się do adresatki, na potwierdzenie przytaczając prośbę poety z listu do Joanny Bobrowej z 18 stycznia 1845 roku: „Nie śmiej się ze mnie, Pani, proszę, ani posądzaj o żadną egzaltację wymuszoną i sternostwo angielskie, głupio sentymentalne"19.

Warto jednak zwrócić uwage, że, po pierwsze, list do Bobrowej był pisany w okresie religijnym, a wtedy poeta odrzucał sentymentalizm również $\mathrm{w}$ relacjach z matką ${ }^{20}$. Po drugie, cały opis pastereczki z Pornic był pisany z punktu widzenia mistyka obcującego z duchami, a deklaracja odrzucenia sternizmu miała przekonać Bobrową, że ani wieśniaczka, ani poeta nie odgrywali sielanki, ale obcowali ze sobą duchowo. Po trzecie, dystans do konwencji sentymentalnej przejawiał się również przed konwersją, i to także w tych najbardziej sentymentalnych listach:

Ty wiesz, droga! jakem ja niegdyś nie lubił egzaltacji próżnej i wielkim nieszczęściem nie usprawiedliwionej - lecz teraz nasze myśli smutne być

17 K. Cysewski Listy Słowackiego do matki. Problem obrazu autora, w: Poetyka przemiany człowieka w twórczości Juliusza Słowackiego: materiały międzynarodowej sesji naukowej, Olsztyn, 22-23 listopada 1995 roku, red. M. Śliwiński, Wyższa Szkoła Pedagogiczna, Olsztyn 1997; M. Kuziak Kreacje epistolograficzne...; K. Wybraniec Kobieta jako adresat listów/uliusza Słowackiego, w: Sztuka pisania...; szczególnie zaś: E. Nawrocka "[...] list to nie słowo". O listach Słowackiego do matki, w: Sztuka pisania...

Z. Sudolski Juliusz Słowacki jako epistolograf-od apologii do kryzysu romantycznej epistolomanii, w: Dziewiętnastowieczność. Z poetyk polskich i rosyjskich XIX wieku, red. E. Czaplejewicz, W. Grajewski, Ossolineum, Wrocław-Warszawa-Gdańsk-Kraków 1988, s. 263. Por.: tegoż Polski list romantyczny, Wydawnictwo Literackie, Kraków 1997, s. 41.

Z. Sudolski Juliusz Słowacki jako epistolograf..., s. 263, list do Bobrowej: Korespondencja Juliusza Słowackiego, oprac. E. Sawrymowicz, Zakład Narodowy im. Ossolińskich, Wrocław-Warszawa-Kraków 1963, t. 2, s. 69-73 (cytowany fragment: s. 71). 
mogą, a że kto nas obaczy chodzących w ciemności albo się patrzących w blade oczy księżyca, ten już by szaleńcem był, gdyby się szydzić odważył. Tak więc najpiękniejszy stan duszy, to jest jej anielskość, stała się nam dozwoloną i zwyczajną - wszak nieprawdaż? A teraz bez egzaltacji i prosto Ci napiszę, że Ty zajmujesz pierwsze miejsce w sercu moim gdybym umierał, kazałbym spalić i odnieść $C$ i serce moje, bo jego popioł do nikogo innego nie należy. [326; 16.02.1841]

Na pomysł „wojażerowania serca” wpadł jednak nie on, a Eglantyna Pattey, zaprzyjaźniona córka gospodyni pensjonatu, w którym mieszkał w Genewie. Słowacki przytacza go z ironią:

Panna Eglantyna z Lyonu, gdzie teraz bawi, pisuje do mnie długie listy bardzo miłe i sentymentalne. Odpisuję jej w podobnym guście i tak skracamy sobie czas oddalenia. Raz wariatka mówiła mi, że gdybym ja umarł, toby ona moje serce w urnie srebrnej piechotą do kraju zaniosła... ale ja wolę nie umierać, niż takim sposobem wojażować... [113; 24.04.1833]

Na tym przykładzie widać, jak zawikłany jest los „pomysłów sentymentalnych", jak niejednoznaczny stosunek do nich. Motyw „wojażerowania” serca, wyśmiany w liście do matki z roku 1833, zostaje wykorzystany na serio (z podkreśleniem, że mówi się już „bez egzaltacji i wprost”) osiem lat później. Cała ta korespondencja do czasu konwersji jest pełna płaczu, spacerów po cmentarzu, rysowania nagrobków, nawiązań do romansów ${ }^{21}$. Słowacki podróżuje wszak nie tylko śladami Byrona, ale i postaci z Nowej Heloizy (w pokoiku genewskim wiesza nawet cztery sztychy ilustrujące powieść Rousseau).

Poważnie potraktowany sentymentalizm nie daje się jednak sprowadzić do stylu literackiego czy stereotypu emocjonalnej ekspresji. Jak wskazują prace Williama Reddy'ego, Collina Campbella, Grahama Johna Barker-Banfielda, Michaela Bella ${ }^{22}$, był on swoistym projektem

21 Por. np.: „Mogiłka na Père la Chaise, w której leży mój młody przyjaciel, suchotnik Z[ienkowicz], przyjmie mnie zapewne z cichą radością - i mnie też najmilej, bo najsmutniej, będzie usiąść na niej i podumać o pięcioletnich wędrówkach. Zbierze się więcej lat i wędrówek, i łez, i wspomnień, aż mi Bóg usiąść pozwoli pod tą śliweczką, która na grobie dobrej mojej Babki teraz zapewne stoi białymi kwiatami okryta" [293; 2.04.1838]. sity Press, Cambridge 2001; C. Campbell The Romantic Ethic and the Spirit of Modern Consumerism, Basil Blackwell, Oxford 1989; G.J Barker-Banfield The Culture of Sensibility. Sex and Society 
antropologicznym. Campbell dowodzi, że w jego ramach doszło do sekularyzacji introspekcyjnych praktyk protestanckich: skupienie na własnych uczuciach i ich ekspresji zostało utożsamione z dobrem i wrażliwością. Nie tylko pozytywne emocje, ale również smutek, ból czy desperacja mogą sprawiać przyjemność - w szczególności, jeśli są współodczuwane, a więc odbierane przez podmiot z dystansu, czy wręcz wyobrażane. Taka postawa staje się podwaliną hedonizmu wyobraźni charakterystycznego dla nowoczesności.

Przyjrzyjmy się zatem, jak łączy się z narracyjnym postrzeganiem własnej tożsamości w korespondencji Słowackiego.

\section{„Hrabia jutro"}

Wiesz, Mamo kochana, powiem Ci to, czegom nikomu nie mówił w dzieciństwie, kiedy byłem egzaltowanie nabożny, modliłem się do Boga często i gorąco, żeby mi dał życie najnędzniejsze - żebym był pogardzony przez cały wiek mój - i tylko, żeby mi za to dał nieśmiertelną sławę po śmierci. Widząc teraz, jak się skierowały wszystkie okoliczności i uczucia moje, widzę wyraźnie - i czasem przekonany jestem, że jakaś nadprzyrodzona moc podchwyciła moje dziecinne prośby i dotrzymuje mi układu. Straciłem nawet nadzieję być kiedyś szczęśliwym - i przysięgam Ci, Mamo, że nigdy nawet o żadnym szczęściu, o żadnej przyszłości nie myślę... [40-41; 24.01.1832]

Poeta ma dwadzieścia trzy lata, mieszka w Paryżu i właśnie odebrał list z przekazem, co wywołało falę samoponiżenia i dziękczynienia matce (choć pieniądze pochodzą z kapitału zostawionego Słowackiemu przez ojca). Przytoczone wspomnienie z dzieciństwa pełni zatem funkcję usprawiedliwienia stanu teraźniejszego i wpisania go w szerszy sens - przyszłej sławy. Podobną orientację czasową ma urodzinowe podsumowanie:

Gdybym miał co do wyznania, uczyniłbym $\mathrm{Ci}$ tu, kochana Mamo, spowiedź ogólną i szczerą, zacząwszy od mego od Was wyjazdu - ale prawdziwie, że nie popełniłem żadnych przekroczeń, nic sobie nie

in Eighteenth-Century Britain, Chicago University Press, Chicago 1992; M. Bell Sentimentalism, Ethics and the Culture of Feeling, Palgrave Macmillan UK, Basingstoke 2000. 
wyrzucam, więc pobłogosław mi, Matko, na moją dalszą wędrówkę... $[123 ; 23.08 .1833]^{23}$

Teraźniejszość jawi się jako punkt na wyznaczonej trajektorii, miejsce, z którego ocenia się dotychczas przebytą drogę i ustala kierunek dalszej wędrówki, ku horyzontowi przyszłości (takie wyobrażenie o orientowaniu w czasie tożsamości nowoczesnej mają Taylor i Giddens). Innym razem jednak Słowacki widzi teraźniejszość jako moment zawieszenia, oczekiwania na stojący pod znakiem zapytania dalszy ciąg:

Nie wiem, dlaczego, ale lata galopem przede mną uciekają. Może to dlatego, że teraźniejszość uważam za czas czyśćcowej próby - i odkładam do szczęśliwszych czasów używanie tego świata; dlatego nic mię teraz nie bawi, nie cieszy, zdaje mi się, że sobie przygotowuję przyszłość a ta przyszłość może nigdy dla mnie nie nadejdzie. [140; 3.01.1834]

Dziesięć miesięcy później zauważa:

Biada tym, którzy zasmakują w błędnym życiu na świecie i przywykną do nadziei znalezienia czegoś dobrego na końcu wędrówki. W oczekiwaniu takim wszystko teraźniejsze niesmaczne. $\mathrm{Z}$ tego względu już się bardzo poprawiłem - pan D z i ś lepszy od hrabiego Ju tro. [179; 7.11.1834]

Autorefleksja prowadzi Słowackiego do uznania,że jego sposób orientowania siebie w czasie jest dla niego szkodliwy. Postanawia się zatem "poprawić", czyniąc z tej zmiany temporalnie zorientowany, podlegający ewaluacji projekt. Jednakże, mimo tych wysiłków wpisujących się w dominującą mitologię nowoczesności, dla Słowackiego „pan Dziś” pozostaje na usługach „hrabiego Jutro".

\section{"Starość musi mieć także wielkie przyjemności"}

Czekając w Bejrucie na statek do Europy, poeta pisze: „Mnie miło było polować na piaskach, rysować szkice pomników, chatek, dumać i myśleć o tym, że jestem w Egipcie" [248; 17.02 1837].Z tych zajęć tylko polowanie jest nastawione na zmysłowe, cielesne doświadczanie tu i teraz. Szkicowanie opiera się

23 Zob. również: [171; 21.08.1834]. 
na zapośredniczeniu percepcji przez dystans estetyczny i podporządkowanie jej porządkowi przyszłego wspominania (jest odpowiednikiem dzisiejszego robienia zdjęć). „Dumanie o tym, że jest się w Egipcie” natomiast w ogóle nie potrzebuje materialnego świata i cielesnego doświadczenia: jedną z głównych atrakcji bycia w Egipcie (może najważniejszą) staje się sama świadomość bycia w Egipcie.

Słowacki czerpie zatem przyjemność raczej z pracy własnej świadomości niz z doznań zmysłowych - jest nowoczesnym hedonistą Campbella. Stymulatorami są tu nie rozkosze cielesne, ale emocje wywoływane i modyfikowane przez podmiot dzięki wyobraźni. Może być to fantazja o kupieniu niewolnicy, przebraniu jej za pazia i byciu „nowym Larą z nową Gulnarą” [276;3.10.1837], wyobrażenia o przyszłej sławie, ale także śmierć dziecka, którego nigdy nie spotkał²4.

Rzeczywistość staje się surowym materiałem, pożywką dla wewnętrznych przeżyć wyzwolonych od oporu materii, ograniczeń społecznych, a nawet czasu. Jeszcze będąc w Bejrucie Słowacki zauważa:

a mam ufność, że ta podróż zupełnie bezużyteczną nie będzie, choćby tylko promień takich pięknych wspomnień miał upaść na starość moją, jeżeli dożyję starości... [254; 19.02.1837]

Słowacki relacjonuje podróż na Wschód przez orientalizujące soczewki" a zarazem patrzy na teraźniejszość przez pryzmat tego, jak będzie je wspominał w przyszłości. W czasie innej podróży, wycieczki w Alpy Szwajcarskie z rodziną Wodzińskich, projektowanie wspominania staje się elementem towarzyskiej gry:

Tam ułożyliśmy, że kiedyś, jeżeli wszyscy razem będziemy w Warszawie, Pani W[odzińska] wyda bal kostiumowy, na który każdy z nas przywdzieje 
swój podróżny ubiór, a nawet owe grube trzewiki, w których łaził po skałach. Projekt ten bardzo mi się podoba. Jakie by to było smutne i zachwycające uczucie, po 10 lub 20 latach ubrać się tak, jak się człowiek ubierał młody, będąc na obcej ziemi - jak miło by było powinszować sobie wtenczas przebytych bied - i młodym o przeszłości rozpowiadać... Starość musi mieć także wielkie przyjemności - jako pora roku jesienna. [173-174; 28.09.1834]

Zdaniem Svetlany Boym na początku XIX wieku kultura salonowa zaczyna celebrować nostalgię, a towarzyskość zmienia się w „rytualne upamiętnianie utraconej młodości, wiosen, tańców, szans"26. Jeszcze w Alpach podróżnicy wyobrażają sobie bal w Warszawie, na którym starsi i w spłowiałych strojach będą upamiętniać fakt, że ich wycieczka - spędzona m.in. na wyobrażaniu sobie tej chwili wspominania - bezpowrotnie przeminęła. Doświadczanie teraźniejszości zostaje zatem zapośredniczone przez wyobrażenie o wspominaniu, „piękna chwila” - jak pisze przy innej okazji Słowacki - staje się „skarbem przydatnym do wspomnień" [89; 8.12.1832].

Poeta nie poprzestaje jednak na biernym gromadzeniu tych „skarbów”. Obserwując szkolną majówkę w genewskim pensjonacie, wspomina melancholijnie własne dzieciństwo, ale podejmuje również działanie z myślą o przyszłości:

Wtenczas przypomniałem sobie Czackiego - przypomniałem własne uczucia, jakich doznawałem odbierając oklaski na egzaminach - i prosiłem wizytatora, aby mi prezentował pierwszego ucznia... Natychmiast wizytator przyprowadził mi za rękę małego 12-stoletniego chłopczyka, trochę chorego wtenczas... Wziąłem go za rękę, powiedziałem mu imię mojej kuzynki [Polski] - zapytałem, czy ją zna? Powiedziałem mu kilka pochlebnych rzeczy i dałem mu ładny medal mój... prosząc, aby sobie kiedyś, będąc starszym, przypomniał tę chwilę. [126; 23.08.1833]

Słowacki chce powtórzyć to samo przeżycie w innym rozpisaniu ról: tworzy chłopcu materiał do przyszłego nostalgicznego wspomnienia, którego to on - podróżnik z odległego kraju - będzie przedmiotem. Nie uczucia i pamięć dziecka są tu w istocie ważne, a własna fantazja o nich. 
Innym razem Słowacki zaprasza młodziutkie włoskie siostry na podwieczorek. Jedna z nich mu się oświadcza, ostentacyjnie wychodząc z roli, jaka została jej przypisana w sentymentalnym teatrze wyobraźni:

Na miejscu tych Włoszek, Sabinek w odwrotnym znaczeniu, dziewczątka francuskie albo niemieckie lubiłyby mię i wspominałyby długo, jak odjadę; a ja właśnie tego chciałem bawiąc je, aby kiedyś, po kilku latach, wspomniały o mnie, zobaczyły oczyma wspomnień mój salonik, mój fortepianik, moją lampę przed lustrem i powiedziały do siebie: „Jak my się dobrze bawiły u tego forestiere; kto on taki? skąd? gdzie zniknąt?". [287; 22.02.1838]

Słowacki nie kryje narcystycznych pobudek własnego działania: przypadkowe osoby mają stać się medium wyobrażonej pamięci o nim. Często zresztą przytacza dowody na to, że ktoś go pamięta czy wspomina: czy chodzi o córkę drezdeńskiej gospodyni, u której się niegdyś zatrzymał, czy Marię Wodzińską, która miała zaręczyć się z Fryderykiem Chopinem, bo przypominał jej pierwszą miłość, czyli Słowackiego ${ }^{27}$.

\section{Tam, gdzie utracona teraźniejszość nabiera sensu}

Myślenie o życiu jako materiale do wspominania ma jeszcze jeden aspekt: daje namiastkę obcowania z bliskimi. Słowacki wyobraża sobie koniec swojej wędrówki jako moment snucia opowieści twarzą w twarz, powtórnego odczytania listów wysłanych przez lata. Odbędzie się to w miejscu znanym i oswojonym, ale niekoniecznie związanym z dzieciństwem: może być to Krzemieniec, domek na południu Francji, który kupią sobie wspólnie z matką, czy Warszawa, gdzie wszyscy się zjadą do Wodzińskiej.

Wizję taką może wywołać szczegół dnia codziennego, przenosząc doświadczający podmiot zarazem w przeszłość i przyszłość:

A propos - wyborne są brzoskwinie, o których Jan Śniadecki zawsze wspominał. Kiedyś i ja na starość, kiedy z Wami zasiędę do stołu - jak

Por. „Mówią, że się Szopen z Marią Wodzińską, a niegdyś moją Marią, ożenił - może poszła za niego trochę z przyjaźni dla mnie, bo mówią ludzie, że Szopen do mnie jak dwie krople wody podobny. Jak to sentymentalnie pójść za człowieka podobnego temu, którego się pierwszą miłością kochało" [292; 2.04.1838]. 
Jan z siwym włosem i z białymi, najeżonymi brwiami (bo brwi mi się trochę zagęściły) - wtenczas będę gadał o paryskich brzoskwiniach, bo wyborne - jak lody się rozpływają. [74; 3.09.1832]

Innym razem poeta sytuuje scenę wspominania w znanym sobie z dzieciństwa miejscu:

Kiedyś, usiadłszy z Tobą na cmentarzyku krzemienieckim będę Ci opowiadał o grobach dawnych i wielkich ludzi i o pomnikach starych wieków. A słuchając moich wspomnieć będziesz się tak uśmiechać, jak niegdyś słuchając marzeń moich o przyszłości. [254; 19.02.1837]

Wyobrażony uśmiech matki jest tu zwieńczeniem tożsamościowej opowieści - jak kiedyś Salomea uśmiechała się, słysząc plany syna, tak będzie się uśmiechać, kiedy ten opisze swoje wspomnienia. Marzyć można tak samo o przyszłości, jak i przeszłości, ponieważ sama teraźniejszość nigdy do wyobrażeń nie dorasta:

Wojaż bardzo wiele daje wyobrażeń, szkoda tylko, iż wszystko ukazuje mniej pięknym, niż było w imaginacji - i potem zostaje w pamięci dwa obrazy - jeden taki, jaki być powinien, oczami wymalowany; drugi piękniejszy, dawniej utworzony przez imaginacją. Kiedyś utworzy się trzeci, najpiękniejszy, z imaginacji i z sennego przypomnienia - i połączy w sobie wszystko najpiękniejsze z tych trzech obrazów. [27-28; 20.10.1831]

Gdy proces ten już się dokonał, niebezpiecznie jednak wracać do miejsca stanowiącego przedmiot nostalgii:

wróciwszy do Genewy, zamiast przywitać się z drzewami ogrodu, gdzie sobie przez trzy lata marzyłem - zamiast odpocząć w pokoiku, gdziem przywykł był leżeć spokojnie - zamiast tej melancholii, jaką by mię przeniknął widok miejsc, gdziem latał po murawach z młodziutką Marią, co mię kochała krótko, ale mocno [...] - zamiast tego wszystkiego znajdę dóm w mieście czarnym i posępnym. $O$, nie wrócę [już więcej] do Genewy, a nawet na krótko wrócić smutno mi będzie. Ja chciałbym latając [uczynić], żebym się wszystkie miejsca zasuszały, kamieniały w takiej postaci, jakimi je zostawiłem, [i żebym ki]edyś drugą podróż 
mógł rozpocząć pełną pamiątek - lecz niestety, wszystko się odmienia. [294-295; 19.05.1838]

Nie można odbyć drugiej podróży w przestrzeni pośród „skamieniałych" pamiątek. Jeśli autobiografia, jak wskazują Małgorzata Czermińska i Elżbieta Rybicka $^{28}$, rozwija się nie tylko w czasie, ale i przestrzeni, to nie da się wrócić do tego samego miejsca, jak nie da się wejść dwa razy do tej samej rzeki. To pamięć i wyobraźnia - nie fizyczna podróż - mogą przenieść podmiot w znaczącą przestrzeń, „zasuszoną” jak inne „skarby do wspomnień”.

Powrót nigdy nie jest zatem możliwy: jest fantazją o momencie, w którym życie okaże się sensowne. Słowacki, świadomy, że „źle ulepione serce człowieka - przeszłość nie powinna się nam piękniejszą wydawać, niż była" [139; 30.11.1833]", wciąż snuje jednak fantazje o domu: miejscu, w którym będzie mogła odbyć się scalająca opowieść: „Mamo moja, jakie by to były czarujące wspomnienia, gdybym kiedyś między Wami mógł przypominać i o przeszłości marzyć!" [169; 21.08.1834]

\section{Nostalgiczna rebelia}

Na marzeniach o przeszłości zamyka się swoiste koło ukazujące sposób odnoszenia się do własnych doświadczeń na planie czasowym. Najpierw jest projekt, marzenie, kulturowo ukształtowane wyobrażenie. Później następuje zderzenie z rzeczywistością, która odsłania złudność wcześniejszych wizji. Wobec tego zaczyna się kolekcjonować i tworzyć „skarby do wspomnień” rozczarowująca rzeczywistość doświadczana jest z perspektywy „przyszłego wspominania” opartego na idealizacji. Wspominanie zaś staje się „marzeniem o przeszłości".

W ten sposób zarówno przyszłość, teraźniejszość, jak i przeszłość uwalniają się od reguł świata społecznego i podlegają kształtowaniu przez podmiot, hedonistycznego „artystę wyobraźni”. Tęsknotę za dzieciństwem zastępuje zatem nostalgia za przyszłością, z perspektywy której rozczarowująca teraźniejszość będzie miała urok i sens. I dopiero wtedy - dzięki opowieści snutej w wyobrażonej swojskiej przestrzeni - będzie można się w tej, utraconej już, teraźniejszości zadomowić.

28 Zob. M. Czermińska Miejsca autobiograficzne. Propozycja w ramach geopoetyki, "Teksty Drugie” 2011 nr 6. E. Rybicka Auto/bio/geo/grafie, „Białostockie Studia Literaturoznawcze” 2013 nr 4. 
Formuła „nostalgii za przyszłością" jest przy tym mniej paradoksalna, niż na pozór mogłoby się wydawać. Svetlana Boym zauważa, że „Nostalgia jest uczuciem straty i wykorzenienia [displacement], ale jest również romansem z własnymi fantazjami"29. O ile na początku sam termin, ukuty w 1688 roku przez szwajcarskiego lekarza Johannesa Hofera, odnosił się do smutku z powodu opuszczenia stron rodzinnych, w XIX stuleciu nostalgia staje się przede wszystkim nieuleczalną tęsknotą za innym czasem. Zazwyczaj przeszłością - ale nie zawsze.

W szerszym rozumieniu, nostalgia jest buntem przeciw nowoczesnemu rozumieniu czasu, czasu historii i postępu. Osoba nostalgiczna pragnie zatarcia historii i zmienienia jej w prywatną albo wspólnotową mitologię, pragnie móc ponownie odwiedzić jakiś moment w czasie, tak jak odwiedza się miejsce, odmawia przy tym poddania się nieodwracalności czasu, która jest zmorą człowieka. ${ }^{30}$

Podmiot nostalgiczny uosabia zatem najważniejsze cechy kondycji nowoczesnej - samoświadomość, refleksyjność, poczucie wyobcowania ze świata ${ }^{31}$ ale nie poddaje się wierze w postęp. Fantazjując, stawia opór triumfalnej opowieści o rozwoju opartym na sprawczości i dążeniu do wyznaczonych celów, któremu implicytnie hołdowali Taylor i Giddens. Gdy u narratywistów jaźń rozpoznaje własną sprawczość poprzez poddanie się logice liniowego, nieubłaganego czasu, nostalgik próbuje go pokonać, czyniąc go zakładnikiem własnej wyobraźni.

Tym samym Słowacki wpisuje się w tradycję refleksji nad kondycją nowoczesną nazwaną przez Boym „od-nowoczesnością"32 (offmodernism) - krytyczną zarówno wobec „nowoczesnej fascynacji nowością”, jak i „ponownego

S. Boym The Future of Nostalgia, s. xiii.

Tamże, s. xv. Konsultacja przekładu O. Kaczmarek. W innym miejscu Boym zauważa, że nostalgia może mieć wymiar prospektywny: fantazje o przeszłości wytwarzane na potrzeby teraźniejszości kształtują bowiem przyszłość. Tamże, s. xvi.

B. Turner A Note on Nostalgia, "Theory, Culture \& Society” 1987, vol. 4, issue 1.

Tłumaczenie off-modernity por. I. Kurz Prawdziwe? Między jawq a snem. O filmach Anny Baumgart, "Magazyn Szum”, publ. 29.11.2013, http://magazynszum.pl/krytyka/iwona-kurz-o-annie-baumgart, 18.08.2018). W innym miejscu Kurz proponuje również terminy "a-modernizm” albo "de-modernizm” (I. Kurz Ścieżki nowoczesności, "Przegląd Humanistyczny” 2013 nr 1). Sama Boym podkreśla, że przedrostek off ma zmylać kierunki, skłaniać do zbaczania z utartych szlaków. S. Boym The Future of Nostalgia..., s. xvi-xvii. 
wynalezienia tradycji"33. Jak wielu innych przedstawicieli tego podejścia, jest emigrantem z peryferii, dla którego „twórcze przemyślenie nostalgii nie było tylko środkiem artystycznym, ale strategią przetrwania"34. Zarazem wyobcowany, sentymentalny, hedonistyczny i krytyczny wymyka się dominującym narracjom. Pozbawiony witalności trickstera niesie z sobą jego przewrotność: zmusza do przemyślenia zastanych konceptualizacyjnych ram.

\section{Abstract}

\section{Agata Sikora}

INDEPENDENTSCHOLAR

Nostalgia for the Future: Life as a Story in Juliusz Słowacki's Letters to His Mother

Drawing on Charles Taylor and Anthony Giddens's concepts of narrativism, Sikora examines how the Polish Romantic poet Juliusz Słowacki constructs his identity in his letters to his mother, Salomea Bécu. Keeping in mind the genre differences between diaries, memoirs and letters, as well as the framework of sentimental culture, she points to the specificity of this identity project, in which the present is experienced through the prism of an imagined future recollection, while being aware that the task of reflecting is at the same time a task for the imagination. Such a construction of a nostalgic subject, based on Svetlana Boym, is presented as part of the tradition of "off-modernism," which eludes the dominant vision of modernity based on progress.

\section{Keywords}

nostalgia, narrativism, modernity, Juliusz Słowacki, anti-sentimentalism 